\title{
Production Practices of Ititu (Traditionally Fermented Cow Milk) in Selected District of Borena Zone, Oromia Regional State, Ethiopia
}

\author{
Beshir Hussien \\ Oromia Agricultural Research Institute, Yabello Pastoral and Dryland Agriculture Research Center, Yabello, Ethiopia
}

Email address:

beshirhussein02@gmail.com

\section{To cite this article:}

Beshir Hussien. Production Practices of Ititu (Traditionally Fermented Cow Milk) in Selected District of Borena Zone, Oromia Regional State, Ethiopia. Science Research. Vol. 8, No. 2, 2020, pp. 52-58. doi: 10.11648/j.sr.20200802.14

Received: December 17, 2019; Accepted: December 26, 2019; Published: April 28, 2020

\begin{abstract}
The study was conducted at Yabello, Arero and Dire districts of Borana zone, Oromia Regional State, Ethiopia to assess production practices of ititu produced in the study area. A total of 180 households selected purposively from three districts, and then six Kebeles were randomly selected from three districts for the survey study. The result of the survey showed that, among the interviewed households, only $39 \%$ and $3 \%$ wash their hands and wash udder of a cow before milking, respectively. Most pastoral households used pond water for cleaning milk utensils (67\%) followed by a hand-dug well (14\%). According to respondents, itituis made from cow milk by spontaneous fermentation without the addition of any starter culture. The removal of the whey part (i.e. called "Dhama" in local language) from fermented milk is more practiced within 3-4 days of interval and followed by adding the fresh milk to fill Gorfa (The complete process of fermentation takes place for 15 days under room temperature in Gorfa). The results indicated that the quality of traditional ititu was substandard and not safe for consumption. This in general, the production of ititu in the study area requires awareness creation of keeping good hygienic quality for ititu making in order to make it safe from the public health point of view.
\end{abstract}

Keywords: Ititu, Fermented Milk, Cowmilk, Gorfa

\section{Introduction}

Traditional fermented milk products are widely consumed in the entire world. These products are an important supplement to the local diet and provide vital elements for growth, good health [1, 2] and an appreciated flavor. Microorganisms of lactic acid starter cultures used for the conversion and preservation of milk products are unique bioconverters of energy. In the earlier days, fermentation was used to control the growth of harmful bacteria and some pathogens, while making indigenous milk products. The microorganisms principally encountered in the dairy industry are bacteria, yeasts, moulds and viruses. Some of the bacteria (lactic acid bacteria) are useful in milk processing, causing milk to sour naturally. However, milk can also contain pathogenic bacteria, such as Salmonella spp., Staphylococcus aureus, Escherichia coli, Mycobacterium tuberculosis, Listeria spp., Brucella spp. The presence of these pathogenic bacteria in milk emerged as major public health concerns, especially for those individuals who still drink raw milk [3].

Milk processing is one of the oldest traditional practices in Ethiopia, which is generally based on Irgo (traditional fermented milk) [4]. Dairy processing in the country is basically limited to smallholder level and hygienic qualities of products are generally poor [5]. The fermentation process does not require additions of any defined starter culture, rather natural lactic acid bacteria (LAB) spontaneously ferment the milk. Raw milk is either kept at ambient temperature or kept in a warm place to ferment prior to processing [6]. The subsistence farmers in rural areas without dairy facilities are contributing to about $98 \%$ of the annual milk production. Furthermore, dairy processes in the country are mostly restricted to smallholder level and its hygienic quality is low [7]. Milk is a medium that favors the growth of numerous microbial species [8]. Milk from a healthy udder comprises very little microorganisms but it is contaminated with spoilage and pathogenic microbes after the time it leaves the teat of the cow till it is used for further processing. 
The raw milk is further transformed into traditional fermented products like Ergo and Ayibin Ethiopia. Ergo is a traditional Ethiopian fermented milk product, which is frequently manufactured at the domestic level [9]. In rural societies, fermented milk products are used for various purposes [10]. Fermented milk products can be used for consumption as food and beverage and its market value and shelf life are extended over that of raw milk. It is also used as cosmetics by rural people [10]. Such products have been considered, based both on research findings and popular wisdom as more nutritious and health-promoting than fresh milk [10].

Milk and milk products are economically important farm commodities and dairy farming is an investment option for smallholder farmers [4]. Dairy processing plants are few in numbers, much of the milk produced by rural smallholders are processed on-farm using traditional technologies and milk processing is based on sour milk [11]. As reported in [12] the rural dairy production system is not market-oriented and most of the milk produced in this system is retained for home consumption. The level of milk surplus is determined by the demand for milk by the household and calves. The surplus is mainly processed using traditional technologies and the processed milk products such as butter, ghee, Ayib and sour milk are usually marketed through the informal market after the households satisfy their needs [13]

The consumption of milk and milk products vary geographically between the highlands and the low lands and even in the level of urbanization. In the lowlands like Borena, one of the pastoralists group in Ethiopia, where livestock keeping is the main occupation, milk is consumed by all groups of the society. In Borana, pastoralists traditionally ferment cow milk and this product is called ititu. It is considered as one of the special foods and served to many respected guests as well as to weaning-age children and the elderly. It is consumed as a side dish with traditional porridge or thin baked cereal bread [6]. During the traditional production of Ititu, fresh milk is collected in a well-smoked fermenting vessel called Gorfa. It is prepared at $27-30^{\circ} \mathrm{C}$ for $15-30$ days with periodic removal of whey with wooden pipet (Dhumaa) \& the addition of fresh milk every 3-4 days, needs a longer time of fermentation. The process of whey removal and addition of fresh milk is repeated several times until the product is concentrated enough and is ready for consumption [6].

However, there is limited work undertaken regarding the production practice of ititu (traditionally fermented cow milk). Therefore, this work is aimed to characterize the production practice of traditional fermented cow milk Ititu in selected districts of Borana Zone regional state, Ethiopia.

\section{Materials and Methods}

\subsection{Description of Study Area}

The study was conducted in Yabello, Arero and Dire districts of Borana zone, Oromia regional state, Ethiopia. Yaballo is located at a distance of $563 \mathrm{~km}$ from Addis Ababa, the Capital city of Ethiopia. Arero and Dire are located at equidistant $(100 \mathrm{~km})$, each to east and south of Yabello town, respectively.

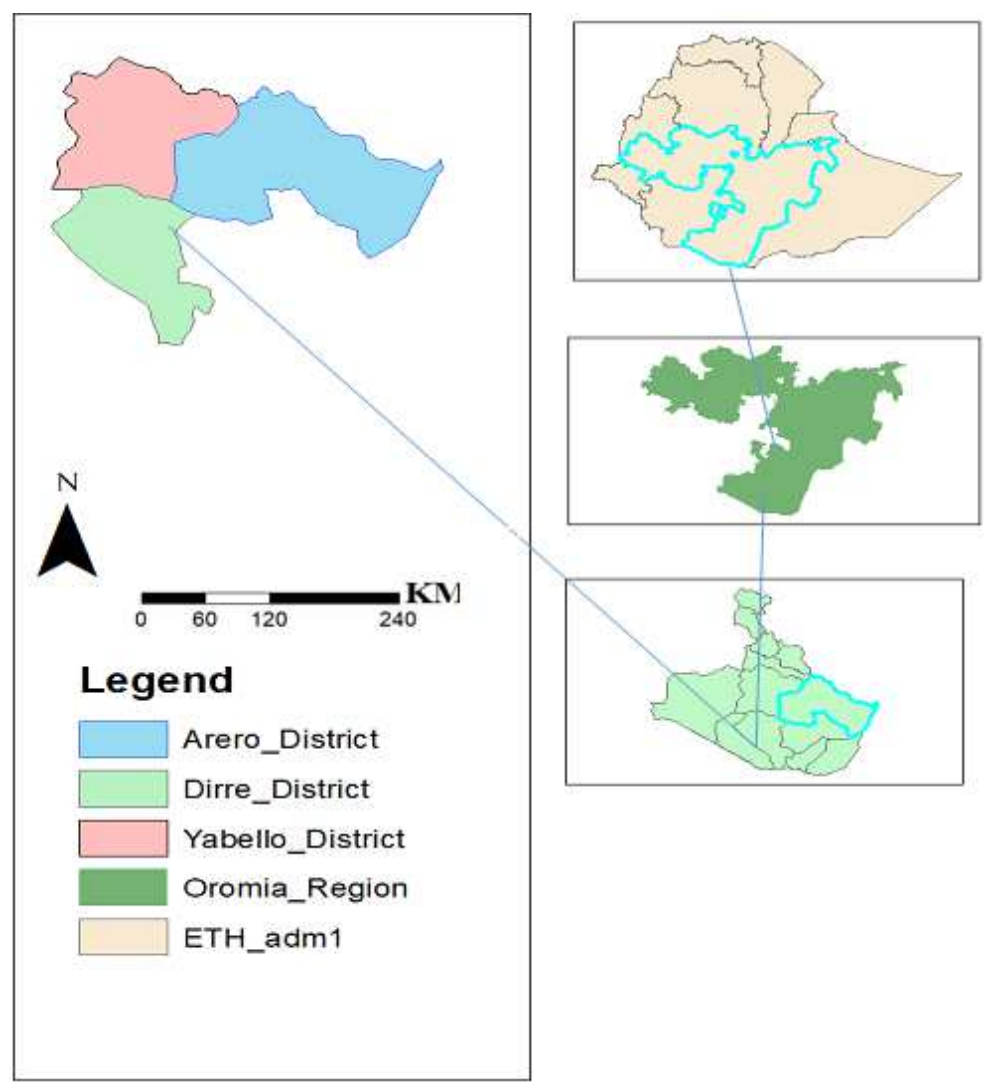

Figure 1. Map of the study area. 
Yabello is located at 1350- 1800 meter above sea level (m.a.s.1.) and it is located between latitude $4^{\circ} 30^{\prime} 55.81^{\prime \prime}$ and $5^{\circ}$ $24^{\prime} 36.39^{\prime \prime} \mathrm{N}$ and longitude $7^{\circ} 44^{\prime} 14.70^{\prime \prime}$ and $38^{\circ} 36^{\prime} 05.35^{\prime \prime} \mathrm{E}$. Borana rangeland is found in the south most part of Ethiopian lowlands occupying about 555,000 of hectares total land area [14]. The mean annual rainfall is about $700 \mathrm{~mm}$ which is bimodal in distribution with $59 \%$ of total annual precipitation occurring from March to May and 27\% from September to November. The mean monthly maximum and minimum temperatures are $19^{\circ} \mathrm{C}$ and $24^{\circ} \mathrm{C}$, respectively [15].

\subsection{Survey}

A formal survey was conducted using open and closed questionnaires. The questioner contained questions on the production and handling practices of ititu. A survey was conducted in Yabello, Arero and Dire district of Borana zone focusing on pastoralists who own cow and produce cow milk in order to get background information regarding production practices of the traditional fermented cow milk ititu in the area. The districts were purposively selected based on the potential of cow possessions and accessibility and willingness of the households to take part in the study. Accordingly, two Kebeles from each district a total of six Kebeles (Derito and Dedim from Yabello, Alona and Afura from Arero, Medacho and Harelo from Dire) were selected randomly. From each of the selected Kebeles, thirty households were randomly selected and thus a total of 180 households were interviewed using a semi-structured questionnaire applying a single-visit multiple-subject diagnostic survey technique [16]. A focus group discussion was also made for cross-checking.

\subsection{Data Analysis}

Qualitative data were analyzed using descriptive statistics. Data collected during the survey were analyzed using the Statistical Package for Social Sciences (SPSS version 20).

\section{Result and Discussion}

\subsection{Household Characteristics}

The result shows that the average number of age respondents was 39.67 (Table 1). The average age of the respondents observed in this study was less than [17] who found that the average age of the respondents was 45 Years in Burie District. The average number of cows per household was 3 and varied from 1 to 20 cows.

Table 1. Mean age of respondents and number of lactating cows (Mean \pm SE).

\begin{tabular}{lll}
\hline Districts & Age structure & Lactating cows per HHs \\
\hline Yabello & $40.23 \pm 3.96$ & $3.15 \pm 0.07$ \\
Arero & $39.89 \pm 3.33$ & $3.36 \pm 0.07$ \\
Dire & $38.90 \pm 3.36$ & $3.17 \pm 0.10$ \\
Total Mean & $39.67 \pm 3.55$ & $3 \pm 0.17$ \\
\hline
\end{tabular}

The major purpose of keeping dairy cows in the study area was for milk and milk production (35\%) followed by reproduction purpose (22\%) (Figure 4)

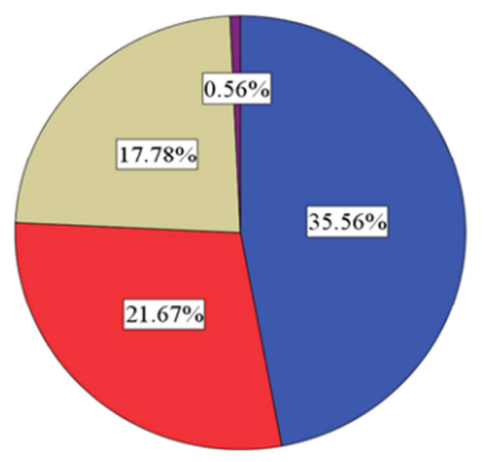

Figure 2. The major purpose of keeping dairy cows in the study area.

\subsection{Sex, Educational and marital Status and Religion of Pastoral Households}

In this finding, the majority of respondents' sex was female (95\%) (Table 2). When males were interviewed; the majority of them direct the interviewer to ask the women. This shows that major dairy activities are done by women in the study areas. The educational status of households was almost illiterate (93\%) and about $4 \%$ of them were educated at primary school (Table 2). The majority of respondents were wakefata $(72 \%)$ followed by Protestant Christian (17\%) (Table 2). The survey result shows that the majority of respondents were married (94\%); while unmarried and widowed respondents were $3 \%$ each (Table 2).

Table 2. Sex, marital status, educational status and religion of household of the study area.

\begin{tabular}{lll}
\hline Parameters & N & Percent (\%) \\
\hline Sex of Respondents & 171 & 95 \\
Female & & \\
Marital Status & 169 & 94 \\
Married & 5 & 3 \\
Single & 6 & 3 \\
Widowed & & \\
Education Level & 168 & 93 \\
Illiterate & 7 & 4 \\
Primary School & 2 & 1 \\
Secondary School & & \\
Religion & 129 & 72 \\
Wakefata & 31 & 17 \\
Protestant & 11 & 6 \\
Muslim & 6 & 3 \\
Catholic & 3 & 2 \\
Orthodox & & \\
\hline
\end{tabular}

\subsection{Milking and Hygienic Practices}

The study showed that milking was mostly performed in the open air near the entrance of a barn $(45 \%)$ followed by in the barn (28\%) (Table 3). The frequency of barn cleaning in the study area was mostly practiced twice per week (49\%) followed by three times per week (39\% (Table 3). All respondents milked their cows twice per day which is in the morning and evening (Table 3). Among the interviewed households, only $39 \%$ and $3 \%$ wash their hands and wash 
teat or udder of a cow before milking, respectively, which mostly practiced in Yabello district $(27 \%)$ (Table 4). The finding was comparable with the finding of [18] who reported that the majority of the respondents' milk producers in pastoral (58-63\%) and agro-pastoral (42.5-45\%) production systems use water from sources other than tap. The result also comparable with the finding of [19] who reported the majority $(64 \%)$ of the respondent milk producers in Ezha district, Ethiopia was using water from non-tap sources for hygienic practices. Such practices could contribute to the poor bacteriological quality of milk [20]. Most households used pond water for cleaning milk utensils (67\%) followed by water from hand-dug well (14\%) (Table 4). About $27 \%$ of respondents boiled their water for cleaning of milking and storage utensils for milk (Table 4). Generally, proper sanitary milking practices were not followed by the majority of the respondents in the study area.

Table 3. Milking and barn hygiene frequency in the study area.

\begin{tabular}{llll}
\hline Parameter & Yabello & Arero & Dire \\
\hline Milking place & & & Overall (n=180) \\
In open area near the entrance of barn & $16(27 \%)$ & $39(65 \%)$ & $26(43 \%)$ \\
In the barn & $26(43 \%)$ & $5(8 \%)$ & $20(33 \%)$ \\
In open area or in the barn & $18(30 \%)$ & $11(18 \%)$ & $14(23 \%)$ \\
Barn cleaning per week & & $31(45 \%)$ & $51(28 \%)$ \\
Twice & $22(37)$ & $32(53 \%)$ & $35(58 \%)$ \\
Three times & $25(42 \%)$ & $36(60 \%)$ & $9(15 \%)$ \\
According to fill of dung & $12(20 \%)$ & $6(10 \%)$ & $3(5 \%)$ \\
Milk frequency per day & & $89(49 \%)$ & $70(39 \%)$ \\
Twice & $60(100 \%)$ & $60(100 \%)$ & $21(12 \%)$ \\
\hline
\end{tabular}

In this finding, the majority of respondents used Okole (made from woven grass) for milking utensils (79\%) while some respondents used plastic containers for milking (6\%). This finding disagrees with that of [21] who reported that about $94 \%$ of the respondents used plastic for milking on the study conducted in Debre-Libanose District, North
Shewa Zone Oromia Region. For the storage of milk, the most utensils used by respondents were Gorfa (fiber made) (81\%) while Cico (made from woven grass) is the least used (3\%) (Table 4). The study shows that smoking and scrubbing of milking and storage vessels were performed by the majority of respondents in the study area $(97 \%)$ (Table 5).

Table 4. Hygienic practices followed during milking in the study area.

\begin{tabular}{|c|c|c|c|c|}
\hline Hygienic practices & Yabello & Arero & Dire & Overall $(n=180)$ \\
\hline \multicolumn{5}{|l|}{ Wash hands before milking } \\
\hline Yes & $27(45)$ & $18(30 \%)$ & $26(43 \%)$ & $71(39 \%)$ \\
\hline \multicolumn{5}{|l|}{ Pre -milking washing teat or udder } \\
\hline Yes & $3(5 \%)$ & $2(3 \%)$ & $0(0 \%)$ & $5(3 \%)$ \\
\hline \multicolumn{5}{|c|}{ Source of water for cleaning milk utensils } \\
\hline Pond & $16(58 \%)$ & $38(63 \%)$ & $19(62 \%)$ & $120(67 \%)$ \\
\hline Motor pipe & $0(0 \%)$ & $0(0 \%)$ & $3(5 \%$ & $3(2 \%)$ \\
\hline Wells & $12(20 \%)$ & $5(8 \%)$ & $8(13 \%)$ & $25(14 \%)$ \\
\hline Boreholes & $7(12 \%)$ & $1(2 \%)$ & $4(7 \%)$ & $12(7 \%)$ \\
\hline Tap water & $7(12 \%)$ & $3(5 \%)$ & $10(17 \%)$ & $20(11 \%)$ \\
\hline \multicolumn{5}{|c|}{ Wash milking utensil with boiled water } \\
\hline Yes & $18(30 \%)$ & $17(28 \%)$ & $13(22 \%)$ & $48(27 \%)$ \\
\hline \multicolumn{5}{|l|}{ Milk utensils used for milking } \\
\hline Okole (made from woven grass) & $41(68 \%)$ & $52(87 \%)$ & $49(82 \%)$ & $142(79 \%)$ \\
\hline Damela (wood made) & $8(13 \%)$ & $9(15 \%)$ & $11(18 \%)$ & $28(16 \%)$ \\
\hline Plastic container & $3(5 \%)$ & $4(7 \%)$ & $3(5 \%)$ & $10(6 \%)$ \\
\hline \multicolumn{5}{|l|}{ Milk utensils used for storage } \\
\hline Gorfa (fiber made) & $41(68 \%)$ & $54(90)$ & $50(83 \%)$ & $145(81 \%)$ \\
\hline Plastic jeryican & $6(10 \%)$ & $8(13 \%)$ & $8(13 \%)$ & $22(12 \%)$ \\
\hline Cico (made from woven grass) & $1(2 \%)$ & $2(3 \%)$ & $2(3 \%)$ & $5(3 \%)$ \\
\hline Sorora (fiber made) & $4(7 \%)$ & $2(3 \%)$ & $2(3 \%)$ & $8(4 \%)$ \\
\hline
\end{tabular}

The result of the study also shows that the main purpose of smoking and scrubbing the milking and storage vessels is to

give good flavor and aroma $(57 \%)$ followed by to increase shelf life of the milk $(43 \%)$.

Table 5. Smoking and Scrubbing of milking and Storage Vessels and purpose.

\begin{tabular}{lc}
\hline Parameters & Prequency \\
\hline Smoking and Scrubbing of Milking and Storage Vessels & \\
Yes & 174 \\
Purpose of Smoking and Scrabbling & 97 \\
Give good flavor and aroma & 102 \\
Increase shelf life the milk & 57 \\
\hline
\end{tabular}




\subsection{Smoking Plant Used in the Study Area}

According to household interviewed, the ten most frequently used plant for smoking milk vessels in the study area were Olea Africana (Ejersa), Balanites rotund foli (Badana Okolee), Dansee, Acacia nilotica (Burquqqee) Terminallabrownii (Bireessa), Premnaschimperi (Xaaxessaa), Veprisglomerata (Karroo), Maeruatriphylla (Dhumasoo), Combretumhereroense Schinz (Kennoo) and Solanum somalense (Hiddiigaagee) (Table 6). According to the respondents, the techniques of application of these plants used for smoking were either only by burning or both burning and immersing of the smoking plant inside the milking and storage vessels. Then when the burning wood diminished due to vigorous rubbing with the internal surface of the milk container, it is put back again into a fire and the rubbing continues with fresh burning wood again. After such vigorous rubbing for about 5 minutes, the finely powdered wood charcoal removed from the inside of the container by cleansing the inner surface with, sossoo, pieces of textile or hair from the tail-end of cattle. The survey result also shows that some smoking plants specially Balanites rotund folia (BadanaOkolee) and Premnaschimperi (Xaaxessaa) were used for smoking of milking utensils like 'OKolee' but Olea Africana (Ejersa) and Daansee were used both for milking and storage vessels and the majority is used for smoking of storage vessel like Gorfa. All districts were used Olea Africana (Ejersa), Balanites rotund folia (Badana Okolee), Daansee, Acacia nilotica (Burquqqee) and Terminallabrownii (Bireessa) as their smoking plant, but Combretumhereroense Schinz (Kennoo) and Solanum somalense (Hiddiigaagee) were not used in Yabello and Arero district respectively (Table 6). This may be due to unavailability of the specific smoking plant in the area.

Table 6. Some common top ten Smoking plant used in the study area.

\begin{tabular}{lllll}
\hline Name of plants & & Study Area & & \\
\hline Local & Scientific & Yabello & Arero & Dire \\
\hline Ejersa & Olea Africana & $\sqrt{ }$ & $\sqrt{ }$ & $\sqrt{ }$ \\
BadanaOkolee & Balanites rotund folia & $\sqrt{ }$ & $\sqrt{ }$ & $\sqrt{ }$ \\
Daansee & - & $\sqrt{ }$ & $\sqrt{ }$ & $\sqrt{ }$ \\
Burquqqee & Acacia nilotica & $\sqrt{ }$ & $\sqrt{ }$ & $\sqrt{ }$ \\
Birreessa & Terminalia brownii & $\sqrt{ }$ & $\sqrt{ }$ \\
Xaaxessaa & Premnaschimperi & $\sqrt{ }$ & $\sqrt{ }$ \\
Karroo & Veprisglomerata & $\sqrt{ }$ & $\sqrt{ }$ \\
Dhumasoo & Maeruatriphylla & $\sqrt{ }$ & $\sqrt{ }$ \\
Kennoo & Combretumhereroense & X & $\sqrt{ }$ \\
Hiddiigaagee & Solanum somalense & $\sqrt{ }$ & $\sqrt{ }$ \\
\hline
\end{tabular}

$\checkmark=$ used by community, $X=$ not used by community

\subsection{Sources of Milk and Fermented Milk Product}

The interviewed households used animals like cow $(65 \%)$ camel $(16 \%)$, goat (14\%) and sheep (5\%) (Table 7) as sources of milk. Cow milk is the major source of milk followed by camel milk in the study area. The result of the survey shows that the majority of milk produced is used for household consumption and the surplus is sold to market as sources of income to buy goods. The respondents consumed cow milk as raw milk alternatively with ititu.

In the study area, naturally fermented milk is the basis for processing the milk into more shelf-stable and consume preferred fermented milk products. All the respondents processed milk in-home through traditional processing techniques. The major traditionally fermented milk products produced in the study area were ititu (41\%) (Ethiopian sour concentrated fermented milk), traditional butter (Dhadhaa) $(40 \%)$ and buttermilk (Arrera) $(40 \%)$. The study shows that tutu is sour concentrated fermented milk which mostly made from cow and rarely from goat milk. Fermented camel milk was locally called Chuche in the study area. Traditional butter (Kibe) is made by churning process from ititu; while defatted buttermilk (Arrera) is another byproduct of ergo obtained after removal of butter (Kibe) after churning. According to the respondents, cheese making was also not traditionally practiced in the study area.

Table 7. Sources of milk and fermented milk product in the area.

\begin{tabular}{ll}
\hline Parameters & (\%) of total respondents \\
\hline Sources of milk for consumption & \\
Cow & $65 \%$ \\
Camel & $16 \%$ \\
Goat & $14 \%$ \\
Sheep & $5 \%$ \\
Fermented milk product in the area & \\
Ititu & $41 \%$ \\
Butter & $40 \%$ \\
Deffated milk (arrera) & $40 \%$ \\
\hline
\end{tabular}

\subsection{Ititu Production and Its Purpose}

According to respondents, ititu is made from cow milk by natural spontaneous fermentation without the addition of any starter culture. Some respondents suggested that it is also made from goat milk but it has no consistency like that of ititu made from cow milk. Souring of milk is practiced at any time when surplus milk is available and mainly during the wet season. The complete process of fermentation takes place for 15 days but for immature ititu, which is locally called 'Kelba', the process of fermentation is only about 2-3 days. The study shows that storage utensil used for the preparation 
of ititu is called Gorfa (made from root fiber of some plants) and it is also used for churning of milk for butter production in the study area. Almost all respondents followed the same procedure for making of ititu in the study area. According to the interviewed households, the procedure for making was: first the Gorfa is washed with water and mainly smoked with Olea Africana (Ejersa), Terminallabrownii (Bireessa), Daansee, Acacia nilotica (Burquqqee) Maeruatriphylla (Dhumasoo) and Combretumhereroense Schinz (Kennoo) were common. Then the fresh raw milk is filled and tightly closing the Gorfa and hanging it in the Sepana (a part of the house in which some tool is hanging on it). The milk becomes traditionally fermented after 3-4 days and more than 4 days in Gorfa under room temperature. Whey liquid (Dhama) is removed from the container by wooden pipette after which fresh milk is added and the removed 'Dhama' was usually drunk by a group of people in the village. Further incubation of fermented milk for about 3-4 days forms 'Kelba (immature ititu)' which is not hard and lacks consistency The removal of the whey liquid (Dhama) from fermented milk is more practiced within 3-4 days of interval and followed by addition of the fresh milk to fill Gorfa. This process continues until the Gorfa is filled with hard curd). The result of the survey indicated that to obtain the hard card which is ititu it takes about 15 days (Figure 3). The traditional procedure for making ititu is shown in (Figure 4). The majority of respondents added the spices locally called 'Fixo' powder cooked with butter during the storage of ititu for purpose of imparting good aroma and flavor while some of the respondents used it for purpose of increasing the shelf life of ititu. During the storage period the curd and the lids are occasionally checked visually for mould, which, if present, is removed by taking off the surface growth. Finally, ititu was remixed by common wood material for about 2 minutes in the Gorfa prior to consumption.

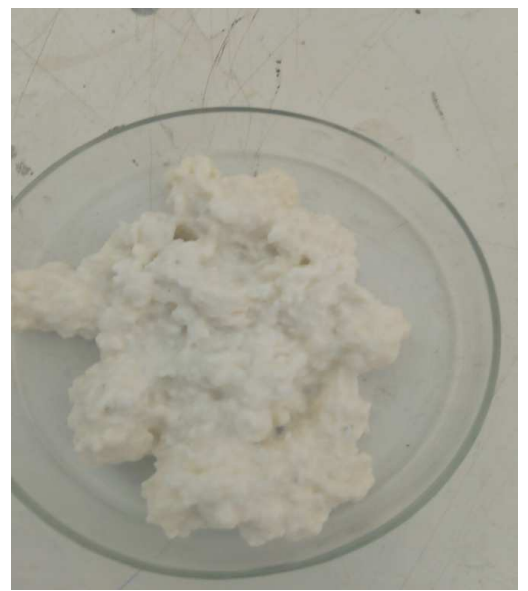

Figure 3. The appearance of ititu when it poured in a pan.

The study shows that the main purpose of ititu making is for home consumption especially for respected persons (Head of households and guests). Respondents also claim that the purpose of ititu making is for further processing it into butter and other milk products for longer shelf life. The study also shows ititu can stay for a long time (i.e. for about 2 months) without deterioration if prepared well with good hygiene. Some of the pastoral respondents suggested also ititu is used for marketing for income generation of pastoralists since it has a higher price compared to the amount of raw milk. Ititu is handled with Gorfa alternatively with plastic Jeryican during marketing in the study area.

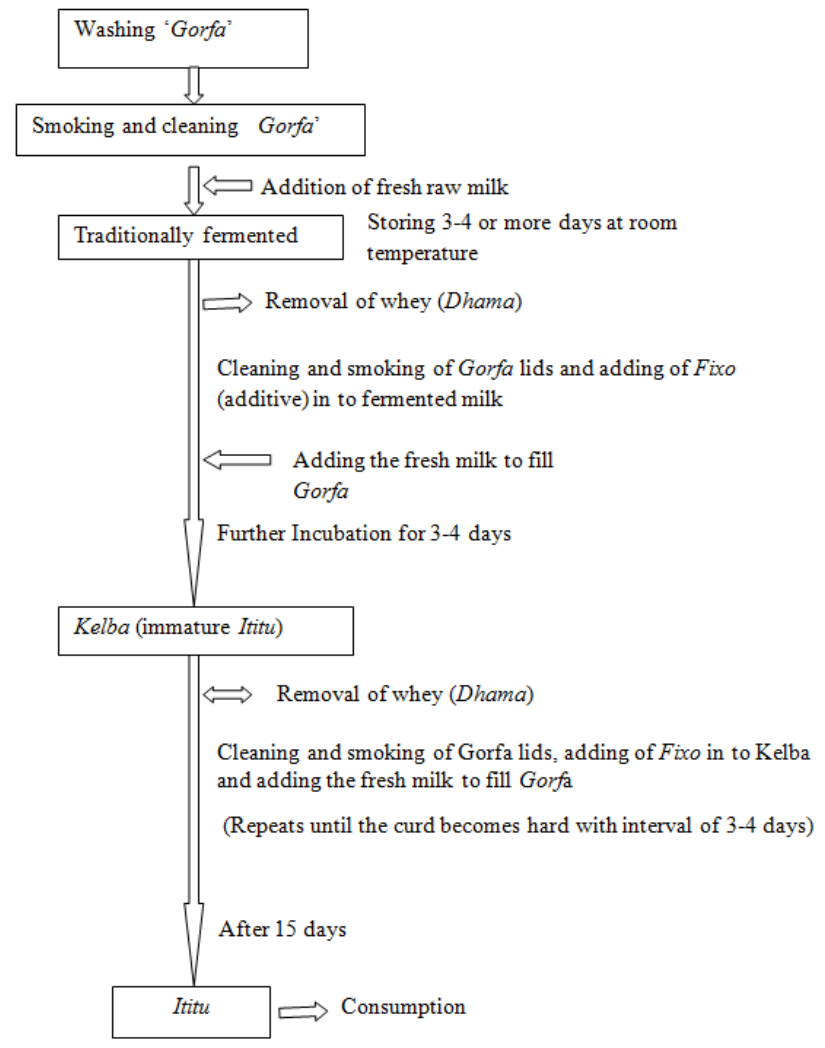

Figure 4. Flow diagram of steps followed during traditionally ititu making by pastoralists in study area.

\subsection{Cause for Spoilage of Ititu}

According to pastoralists in the study area, ititu had more shelf life than unprocessed raw cow milk. Respondents also mentioned that, the causes of spoilage when no properly removing of whey liquid (Dhama) from the curd, no addition of fresh raw milk to ititu during making and no removing of growing mold in the upper layer of ititu during making process in the study area. The other indicators spoilage of ititu reported by the pastoralists includes whey formation, color changes and changes of taste and aroma of the ititu when there are no hygienic practices during production.

\section{Conclusions}

Ititu is made mostly from cow milk by natural spontaneous fermentation without the addition of any starter culture and removing whey liquid (Dhama) from the curd. The process complete fermentation takes place at least for 15 days under traditional production which increases shelf life than unprocessed raw cow milk. But the absence of clean water, fail of regular udder and teats cleaning practice, the 
unhygienic way of milk storage, the poor sanitary condition of the milk vessels and unhygienic processing methods followed during traditional production of ititu may be contributed to the poor microbial quality of in traditionally made ititu in the pastoralists.

\section{Recommendation}

The poor hygienic conditions followed during handling and preparation of Ititu needs for awareness creation and training of pastoralists to follow proper hygienic practices from milking up to production of ititu.

\section{References}

[1] Al-Otaibi, M. M. 2009. Evaluation of some probiotic fermented milk products from Al- Ahsa Markets, Saudi Arabia, American Public Health Association, Washington, USA. American Journal of Food Technology. 4: 1-8

[2] Uccello, M., Malaguarnera, G., Basile, F., D'agata, V., Malaguarnera, M., Bertino, G., Vacante, M., Drago, F. and Biondi, A. 2012. Potential role of probiotics on colorectal cancer prevention. BMC Surgery 12: 45-49

[3] Lingathurai S, Vellathurai P. 2010. Bacteriological Quality and Safety of Raw Cow Milk In Madurai, South India. Webmed Centeraln Microbiology. 1 (10): WMC001029.

[4] Tegegne, A., Gebremedhin, B., Hoekstra, D., Belay, B. and Mekasha, Y., 2013. Smallholder dairy production and marketing systems in Ethiopia: IPMS experiences and opportunities for market oriented development

[5] Zelalem Yilma, and Faye B. 2006. Handling and microbial load of cow's milk and irgo fermented milk collected from different shops and producers in central highlands of Ethiopia. Ethiopian Journal of Animal Production. 6 (2)-2006: 67-82.

[6] Welearegay, H., Yilma, Z. and Tekle-Giorgis, Y., 2012. Hygienic practices and microbiologica quality of raw milk produced under different farm size in Hawassa, southern Ethiopia. Agricultural Research and Review, 1 (4), pp. 113214

[7] Alganesh Tola, Ofodile, L. N. and Fekadu Beyene. 2007. Microbial Quality andchemical composition of raw whole milk from Horro cattle in East Wollega, Ethiopia. Ethiopian Journal of Education and Sciences. Jimma University, Ethiopia. 3 (1): 1-10.

[8] Ahmed, Abdelrahman A., Bernard F., Lucie Blanchard and Sallam. A. 2010. Assessment of quality of camel milk and gariss, North Kordofan State, Sudan. Research Journal of Animal and Veterinary Science. 5 (1): 18-22.

[9] Anteneh Tesfaye Tetemke Mehari and Mogessie Ashenafi 2011. The inhibition of some food borne pathogens by mixed
LAB cultures during preparation and storage of Ayib, a traditional Ethiopian cottage cheese. World Journal of Dairy and Food Science, 6 (1): 666.

[10] Akabanda, F., Owusu-Kwarteng, J. K., Glover, R. L. and Tano-Debrah, K. 2010. Microbiological characteristics of Ghanaian traditional fermented milk product, Nuпи. Nature and Science. 8: 9-10.

[11] Azeze T. and Haji B., 2016. Assessment of post-harvest loss of milk and milk products and traditional mitigation systems in Southern Ethiopia. Assessment, 48.

[12] Gatwech T. 2012. Dairy production, processing and market system: a case study of Gambella, South West Ethiopia (Doctoral dissertation, MSc Thesis. Addis Ababa University, Ethiopia)

[13] Bereda A. Yilma, Z. and Nurfeta A. 2012. Hygienic and microbial quality of raw whole cow's milk produced in Ezha district of the Gurage zone, Southern Ethiopia. Wudpecker Journal of Agricultural Research, 1 (11), pp. 459-465

[14] Borana Zone agricultural and pastoral development office (BPDO). 2008. Yabello, Ethiopia.

[15] Desta S. and Coppock DL. 2004. Pastoralism under pressure: tracking system change in southern Ethiopia. Human Ecology, 32 (4), pp. 465-486.

[16] Van Klink, E. G. M., Corten, J. J. F. M. and Kalokoni, D. M., 1996. Herd monitoring in traditional cattle husbandry as a tool for productivity research and livestock development. Tropical animal health and production, 28 (4), pp. 273-279.

[17] Adebabay Kebede (2009). Characterization of Milk Production Systems, Marketing and on- Farm Evaluation of the Effect of Feed Supplementation on Milk Yield and Milk Composition of Cows at Bure District, Ethiopia. MSc Thesis, Bahir Dar University, Ethiopia.

[18] Tadele Amentie, Mitiku Eshetu, Yoseph Mekasha, Ameha Kebede (2016). Milk post harvest handling practices across the supply chain in Eastern Ethiopia. Journal of Advanced Veterinary and Animal Research 3 (2): 112-126.

[19] Abebe Bereda, Zelalem Yilma, AjebuNurfeta. 2013. Handling, processing and utilization of milk and milk productsin Ezha district of the Gurage zone, Southern Ethiopia. Journal of Agricultural Biotechnology and Sustainable Development, 5: 91-98.

[20] Elmoslemany AM., Keefe, GP, Dohoo IR., Wichtel, JJ., Stryhn, H. and Dingwell, R. T. 2010. The association between bulk tank milk analysis for raw milk quality and on-farm management practices. Preventive veterinary medicine, 95 (12), pp. 32-40.

[21] Mezgeb Workiye, Mekonnen H/mariam and Girma Zewde. 2012. Milk Chemical Composition, Bacteriological Quality and Handling Practices in DebreLibanose District North Shewa Zone Oromia Region. MSc Thesis, Addis Ababa University. Debre Zeit, Ethiopia. 